\title{
Комплексы микромицетов при биоремедиации нефтезагрязненной почвы при засолении с применением микробных композиций
}

\author{
(С) Г.Ф. Рафикова, Е.В. Кузина, Т.Ю. Коршунова
}

Уфримский Институт биологии УФИЦ РАН

Россия, Республика Башкортостан, 450054 г. Уфра, проспект Октября, 69

*Email: rgf07@mail.ru

При внесении углеводородокисляющих бактерий в нефтезагрязненную почву наряду с ускоренной деструкцией нефти отмечено увеличение видового разнообразия комплексов микромицетов. При обработке нефтезагрязнной засоленной почвы микробными композициями формировался более специфичный комплекс микромицетов, основу которого составляли галотолерантные виды, устойчивые одновременно и к умеренным концентрациям нефти в среде.

Ключевые слова: комплексы микромицетов, нефтезагрязненная почва, углеводородокисляющие микроорганизмы.

Нефть и нефтепродукты признаны наиболее опасными загрязнителями окружающей среды. Нефть, попадая в почву, приводит не только к ухудшению ее водного режима и фризико-химических свойств, но и к изменению почвенного микробоценоза, тем самым оказывая влияние на процессы трансформации веществ в почве. Для очистки почвы от нефти используют различные приемы, среди которых наиболее перспективным считается биологический метод с использованием микроорганизмов-нефтедеструкторов. Поскольку одновременно с нефтезагрязнением зачастую происходит засоление грунта в результате утечек высокоминерализованных промысловых вод, немаловажным является использование в таких условиях галотолерантных углеводородокисляющих микроорганизмов [1-4]. О глубине происходящих в нефтезагрязненной и рекультивируемой почве микробных перестроек можно судить по показателям численности и видового состава почвенных микроскопических грибов. При этом характер изменений структуры почвенной микобиоты при загрязнении нефтью и биорекультивации может различаться в зависимости от природы применяемого биопрепарата.

Целью настоящего исследования являлась оценка влияния микроорганизмовнефтедеструкторов (в том числе галотолерантных) на динамику численности и видовой состав микроскопических грибов нефтезагрязненного выщелоченного чернозема.

Исследования проводили в условиях модельного эксперимента с выщелоченным черноземом ( $\mathrm{N}_{\text {общ. }}-0.61 \%$, гумус $\left.-10.46 \%\right)$. Для этого воздушно-сухую почву массой 3 кг помещали в вегетационные сосуды и увлажняли до $60 \%$ от полной влагоемкости. Для оптимизации водно-воздушного режима почвы использовали дренаж, в течение опыта поддерживали влажность почвы и проводили ее регулярное рыхление. В опытные варианты вносили нефть в концентрации $5 \%$ от веса почвы и 50 мл жидкой. Для обработки почвы использовали штаммы углеводородокисляющих бактерий (УОБ) из коллекции микроорганизмов Уфимского Института биологии УФИЦ РАН и ООО «БиохимРеагент». В опыте использовали отдельные культуры галотолерантных УОБ: Pseudomonas hunanensis BCHR-IB-C7 (BKM B-3229D), Yarrowia lipolytica BCHR-IB-U2 
(ВКПМ Y-4382), Mangrovibacter sp. BCHR-IB-L3 (BKM B-3230D); а также композиции УОБ: композиция 1 - Acinetobacter sp. ИБ ДТ - 5.1/1 (VKM B-2753D), Ochrobactrum sp. ИБ ДТ-5.3/2 (VKM B-2754D), Pseudomonas sp. ИБ-1.1 (ВКМ B-28361D), Y. lipolytica BCHR-IB-U2; композиция 2 - Acinetobacter sp. ИБ ДТ - 5.1/1 (VKM B-2753D), Ochrobactrum sp. ИБ ДТ-5.3/2 (VKM B-2754D), Y. lipolytica BCHR-IB-U2; композиция 3 - Acinetobacter sp. ИБ ДТ - 5.1/1 (VKM B-2753D), Ochrobactrum sp. ИБ ДТ-5.3/2 (VKM В-2754D), P. hunanensis BCHR-IB-C7 (BКМ B-3229D); композиция 4 - Acinetobacter sp. ИБ ДТ - 5.1/1 (VKM B-2753D), Ochrobactrum sp. ИБ ДТ-5.3/2 (VKM B-2754D), Mangrovibacter sp. BCHRIB-L3; композиция 5 - Acinetobacter sp. ИБ ДТ - 5.1/1 (VKM B-2753D), Ochrobactrum sp. ИБ ДТ-5.3/2 (VKM В-2754D).

Изучение динамики численности УОБ в почве показало, что все внесенные штаммы микроорганизмов смогли адаптироваться к условиям нефтяного загрязнения и их численность оставалась на относительно высоком уровне в течение всего эксперимента. Наибольшая плотность популяции УОБ наблюдалась в первые 30 суток после постановки эксперимента и в вариантах с внесением микробных композиций составляла в среднем $5 \times 10^{7} \mathrm{KOE} / г$, тогда как в контроле была на порядок ниже. Уровень разложения углеводородов в почве в целом коррелировал с численностью УОБ. Так, максимальных значений степень деструкции углеводородного субстрата достигала в вариантах с внесением композиций 1, 3, 4, 5 и составляла 32-44\% к концу опыта (через 60 суток) против $11.7 \%$ в контроле.

Загрязнение выщелоченного чернозема нефтью стимулировало развитие грибов (табл.), что, вероятно, связано с тем, что углеводороды нефти в умеренной концентрации (5\%) не оказывают столь выраженного токсического эфрфекта и используются данной группой микроорганизмов в качестве субстрата. Использование УОБ для биоремедиации способствовало незначительному уменьшению этого показателя по сравнению с контролем, очевидно, за счет ускоренного разложения углеводородов нефти в почве и быстрого исчерпания источника углерода и энергии, доступного для микромицетов. Через 60 суток после постановки эксперимента в некоторых опытных вариантах наблюдалось незначительное увеличение доли грибов, возможно за счет использования ими в качестве субстрата погибших клеток УОБ. В целом, в течение эксперимента в вариантах с внесением УОБ не было отмечено резкого колебания численности микроскопических грибов.

Из исследованных образцов выщелоченного чернозема было выделено 16 видов микромицетов, относящихся к родам Aspergillus, Microdochium, Mucor, Penicillium, Talaromyces, Trichoderma. В выщелоченном черноземе преобладали грибы из родов Aspergillus и Penicillium. В незагрязненной почве и опытных вариантах доминировал, главным образом, вид Penicillium glabrum. Внесение нефти в выщелоченный чернозем приводило к появлению таких видов как Aspergillus fumigatus, Penicillium lanosum и Talaromyces variabilis, не присутствовавших ранее в незагрязненной фоновой почве. Загрязнение почвы нефтью обуславливало изменение структуры комплекса микромицетов за счет перехода большинства типичных видов в ранг случайных. Аналогичные тенденции были отмечены и другими исследователями при изучении воздействия загрязнения выбросами предприятий цветной металлургии на комплексы почвенных микромицетов [5, 6]. При обработке почвы жидкой культурой микроорганизмовнефтедеструкторов в целом наблюдалось увеличение видового разнообразия грибов при сохранении типичных видов, характерных для фроновой почвы. 
Таблица. Динамика численности микромицетов в выщелоченном черноземе при загрязнении нефтью и внесении микроорганизмов-нефттедеструкторов, $10^{5} \mathrm{KOE} / г$

\begin{tabular}{|c|c|c|}
\hline \multirow{2}{*}{ Варианты } & \multicolumn{2}{|c|}{ Сроки отбора образцов } \\
\hline & 30 суток & 60 суток \\
\hline Контроль & $1.5 \pm 0.06$ & $1.2 \pm 0.06$ \\
\hline НФ (нефттезагрязненная почва) & $5.0 \pm 0.21$ & $2.5 \pm 0.10$ \\
\hline $\mathrm{H} \Phi+\mathrm{NaCl}+$ Yarrowia lipolytica BCHR-IB-U2 & $0.7 \pm 0.03$ & $0.3 \pm 0.01$ \\
\hline $\mathrm{H} \Phi+$ Yarrowia lipolytica BCHR-IB-U2 & $2.1 \pm 0.10$ & $2.0 \pm 0.1$ \\
\hline $\begin{array}{l}\mathrm{H} \Phi+\mathrm{NaCl}+\text { Pseudomonas hunanensis BCHR-IB- } \\
\mathrm{C} 7\end{array}$ & $2.2 \pm 0.11$ & $0.6 \pm 0.04$ \\
\hline $\mathrm{H} \Phi+$ Pseudomonas hunanensis BCHR-IB-C7 & $2.0 \pm 0.11$ & $2.5 \pm 0.12$ \\
\hline $\mathrm{H} \Phi+\mathrm{NaCl}+$ Mangrovibacter sp. BCHR-IB-L3 & $0.3 \pm 0.01$ & $0.4 \pm 0.02$ \\
\hline $\mathrm{H \Phi}+$ Mangrovibacter sp. BCHR-IB-L3 & $0.6 \pm 0.02$ & $1.6 \pm 0.07$ \\
\hline НФ + Композиция 1 & $2.0 \pm 0.10$ & $2.5 \pm 0.12$ \\
\hline НФ + Композиция 2 & $2.5 \pm 0.11$ & $1.5 \pm 0.07$ \\
\hline НФ + Композиция 3 & $3.0 \pm 0.13$ & $2.8 \pm 0.12$ \\
\hline НФ + Композиция 4 & $4.2 \pm 0.18$ & $3.2 \pm 0.15$ \\
\hline НФ + Композиция 5 & $4.0 \pm 0.18$ & $1.0 \pm 0.05$ \\
\hline
\end{tabular}

Совместное воздействие нефти и засоления значительно изменяло видовой состав микромицетов и приводило к формированию более специфичного комплекса. В загрязненных почвенных образцах, обработанных культурами галотолерантных УОБ, и с дополнительным внесением $\mathrm{NaCl}$ элиминировался вид Penicillium glabrum, очевидно, в силу его чувствительности к повышенной концентрации соли. При этом доминирующее положение занимали другие виды, вероятно, более толерантные к засолению Penicillium expansum, $P$. decumbens, $P$. velutinum, что согласуется с данными других исследователей, выделявших некоторые из этих видов из мест природного засоления [7, 8]. В целом, в данных вариантах эксперимента отмечалась тенденция снижения числа видов и изменения видового разнообразия почвенных микромицетов.

В результате кластерного анализа, проведенного по показателю видового сходства, было получено распределение микромицетов по двум группам в нефтезагрязненной почве при внесении УОБ в качестве рекультивирующего агента (рис.). Первую группу составили, главным образом, все варианты эксперимента с внесением $\mathrm{NaCl}$. Это позволяет говорить о том, что наибольшее влияние на почвенную микобиоту оказывало засоление на фроне нефтяного загрязнения. При этом внесение галотолерантных штаммов УОБ не смогло привести к восстановлению исходного состава почвенной микобиоты. Во вторую группу вошли опытные варианты более сходные с контролем по 
видовому составу микромицетов. Внесение в нефтезагрязненную почву тех же штаммов бактерий-нефтедеструкторов, что и в засоленные почвенные образцы, приводило к формированию микобиоты более сходной с таковой контрольного варианта. Максимальное сходство с микобиотой контроля обнаруживалось в вариантах с применением Композиции 3 и Композиции 1 - они составляли отдельный кластер с незагрязненной почвой.

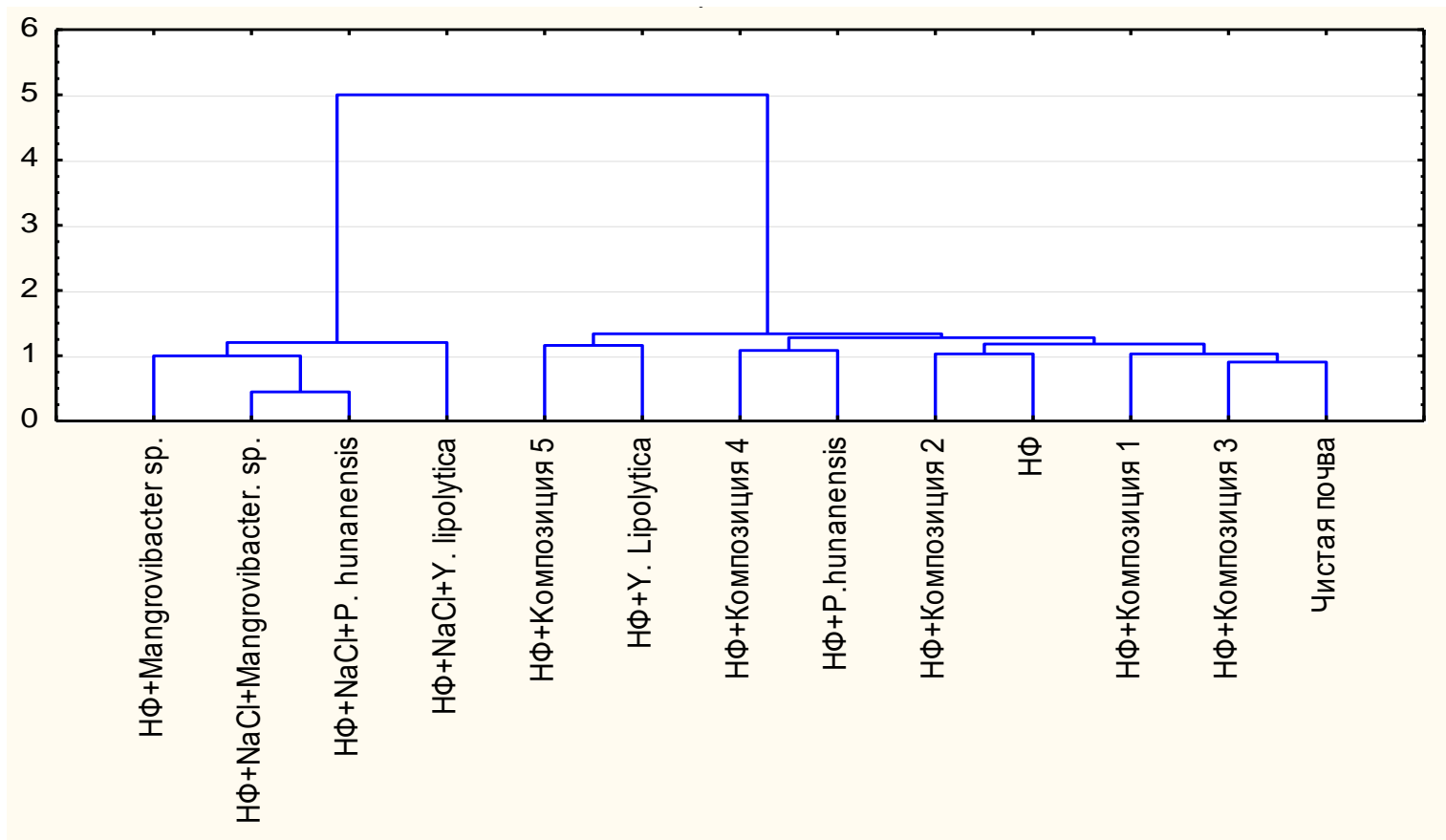

Рис. Сходство видового состава комплексов микромицетов различных вариантов эксперимента с контролем: НФ - нефтезагрязненная почва. По оси абсцисс - варианты эксперимента. Евклидово расстояние, метод Варда.

Таким образом, нефтяное загрязнение совместно с засолением оказывало большее влияние на видовой состав грибов выщелоченного чернозема, чем внесение в почву только нефти. В обработанных УОБ вариантах с засолением на фоне загрязнения формировался более специфичный комплекс микромицетов, основу которого составляли галотолерантные виды, устойчивые одновременно и к умеренным концентрациям нефти в среде. Применение углеводородокисляющих штаммов микроорганизмов для рекультивации почвы, подверженной воздействию нефти, изменяло структуру почвенной микобиоты при незначительном влиянии на численность грибов. Внесение УОБ в нефртезагрязненную почву приводило к увеличению видового разнообразия комплексов микромицетов при сохранении типичных видов, характерных для фоновой почвы; ускоренному разложению углеводородов нести. Применение Композиции 1 и Композиции 3 для рекультивации нефтезагрязненного выщелоченного чернозема наряду с перечисленными положительными эффектами способствовало формированию комплексов микромицетов сходных с фоновыми. Композиция 1, состоящая из микроорганизмов Acinetobacter sp. ИБ ДТ - 5.1/1, Ochrobactrum sp. ИБ ДТ-5.3/2, Pseudomonas sp. ИБ-1.1, Y. lipolytica BCHR-IB-U2, и Композиция 3, в состав которой входят штаммы бактерий Acinetobacter sp. ИБ ДТ - 5.1/1, Ochrobactrum sp. ИБ ДТ-5.3/2, P. hunanensis BCHR-IB-C7, могут быть успешно использованы в качестве основы биопрепаратанефтедеструктора. 
Работа выполнена в рамках ГЗ УФИЦ РАН (№ 075-00326-19-00) по теме № АAАAA18-118022190100-9 на базе УИБ УФИЦ РАН и при поддержке гранта РФФИ № 18-2905025/18 с использованием оборудования ЦКП «Агидель» (Уфра, Россия).

\title{
Литература
}

1. Borzenkov I.A., Milekhina E.I., Gotoeva M.T., Rozanova E.P., Belyaev S.S. The properties of hydrocarbon-oxidizing bacteria isolated from the oilfields of Tatarstan, western Siberia, and Vietnam // Microbiology. 2006. Vol. 75, N 1. P. 66-72.

2. Плотникова Е.Г., Ястребова О.В., Ананьина Л.Н., Дорофреева Л.В., Лысанская В.Я., Демаков В.А. Галотолерантные бактерии рода Arthrobacter - деструкторы полициклических ароматических углеводородов // Экология. 2011. № 6. С. 459-466.

3. Kumar M., Leon V., De Sisto Materano A., Ilzins O.A., Luis L. Biosurfactant production and hydrocarbon-degradation by halotolerant and thermotolerant Pseudomonas sp. // World Journal of Microbiology and Biotechnology. 2008. V. 24. P. 1047-1057.

4. Varjania S.J., Rana D.P., Jain A.K., Bateja S., Upsani V.N. Synergistic ex-situ biodegradation of crude oil by halotolerant bacterial consortium of indigenous strains isolated from on shore sites of Gujarat, India // International Biodeterioration and Biodegradation. 2015. V. 103. P. 116-124.

5. Евдокимова Г.А., Корнейкова М.В., Лебедева Е.В) Сообщества микромицетов в почвах в зоне воздействия алюминиевого завода // Микология и фитопатология. 2007. Т. 41, вып.1. С. 20-28.

6. Евдокимова Г.А., Корнейкова М.В., Мозгова Н.П. Изменения свойств почв и почвенной биоты в зоне воздействия аэротехногенных выбросов Кандалакшского алюминиевого завода // Почвоведение. 2013. № 10. С. 1274-1280.

7. Gunde-Cimerman N., Frisvad J.C., Zalar P., Plemenitas A. Halotolerant and halophilic fungi // Biodiversity of fungi: their role in human life. New Delhi: India. Oxford et IBH Publishing Co. Pvt. Ltd, 2005. P. 69-127.

8. Смолянюк E.B., Биланенко E.H. (Smolyanuk, Bilanenko) Сообщества галотолерантных микромицетов из мест природного засоления // Микология и Фитопатология. 2011. Т. 45, вып. 5. С. 418-426.

\section{Complexes of micromycetes in bioremediation of oil contaminated soil during salinization using microbial compositions}

\author{
G.F. Rafikova, E.V. Kuzina, T.Y. Korshunova
}

Institute of Biology, Ufa Federal Research Center, Russian Academy of Sciences 69 Prospekt Oktyabrya, 450054 Ufa, Republic of Bashkortostan, Russia.

\section{Email: rgf07@mail.ru}

When introducing hydrocarbon-oxidizing bacteria into oil-polluted soil, along with accelerated destruction of oil, an increase in the species diversity of micromycete complexes was observed. When treating oil-contaminated saline soil with microbial compositions, a more specific complex of micromycetes was formed, which was based on halotolerant species that were resistant to moderate concentrations of oil in the medium at the same time.

Keywords: complexes of micromycetes, oil-contaminated soil, hydrocarbon-oxidizing microorganisms. 